\title{
PENYALURAN DANA ZAKAT PRODUKTIF MELALUI POLA PEMBIAYAAN (STUDI KASUS BMT BINAUL UMMAH BOGOR)
}

\author{
Erika Amelia \\ Ikatan Ahli Ekonomi Islam \\ erika_kamil@yahoo.com
}

\begin{abstract}
This article is going to analyze about the evaluation of Zakat Funds Distribution Pattern of Earning Through, Financing Atthe National Agency for Amil Zakat. Observations made by the author for about 4 months, both derived from surveys or direct interviews with parties BAZNAS and BMT Binaul BAZNAS Ummah as well as channel partners from the library or other reference materials. Based on data analysis research is that BAZNAS productive charity has granted funds in accordance with the principles of Islamic rule. The concept of financing as working capital revolving fund that is used by BAZNAS (in this case refers to BMT Binaul Ummah in the distribution) into a concept powerful enough to support the economic empowerment of the poor without a growing culture of consumerism. Because one major goal is to assist the distribution of alms mustahik economic conditions most of which are the poor. Financing revolving fund used by BAZNAS to channel aid funds sourced ZIS working capital for a number of traders and small entrepreneurs in Bogor.
\end{abstract}

Keywords: Zakat; Welfare; BAZNAS

\begin{abstract}
Abstrak
Artikel ini bertujuan untuk mempelajari secara ilmiah tentang evaluasi Dana Zakat Distribusi Pola Produktif Melalui, Pembiayaan Badan Nasional atthe untuk Amil Zakat. Pengamatan yang dilakukan oleh penulis selama sekitar 4 bulan, baik yang berasal dari survei atau wawancara langsung dengan pihak BAZNAS dan BMT Binaul BAZNAS Ummah serta mitra saluran dari perpustakaan atau bahan referensi lainnya. Berdasarkan penelitian analisis data adalah bahwa BAZNAS amal produktif telah diberikan dana sesuai dengan prinsip-prinsip pemerintahan Islam. Konsep pembiayaan bekerja dana bergulir modal yang digunakan oleh BAZNAS (dalam hal ini mengacu pada BMT Binaul Ummah dalam distribusi) menjadi sebuah konsep yang cukup kuat untuk mendukung pemberdayaan ekonomi masyarakat miskin tanpa budaya yang berkembang konsumerisme. Karena salah satu tujuan utama adalah untuk membantu distribusi kondisi ekonomi sedekah mustahik yang kebanyakan miskin. Pembiayaan dana bergulir yang digunakan oleh BAZNAS untuk menyalurkan dana bantuan yang bersumber modal kerja ZIS untuk sejumlah pedagang dan pengusaha kecil di Bogor.
\end{abstract}

Kata Kunci: Zakat; Kesejahteraan, BAZNAS 


\section{PENDAHULUAN}

Ekonomi Islam bertujuan mewujudkan tingkat pertumbuhan ekonomi jangka panjang dan memaksimalkan kesejahteraan manusia (falah). Falah berarti terpenuhinya kebutuhan individu masyarakat dengan keseimbangan makroekonomi (kepentingan sosial), keseimbangan ekologi dan tetap memperhatikan nilai-nilai keluarga dan norma-norma. Sebagai konsekuensinya, diperlukan sejumlah etika pokok dalam ekonomi sehingga falah itu terwujud.

Etika-etika pokok tersebut adalah: (1) Keberadaan tuntunan Allah sebagai pusat kontrol setiap kegiatan ekonomi. Islam memandang bahwa informasi yang dimiliki manusia sangatlah terbatas dan Allah-lah yang lebih mengetahui informasi yang lebih lengkap mengenai apa-apa yang terbaik bagi manusia. Karenanya, apa yang Allah tuntunkan dianggap sebagai sumber rujukan utama dan memberikan tuntunan atas kebebasan yang manusia miliki; (2) Keseimbangan, baik dalam arti tidak berlebih-lebihan, dalam arti keadilan distribusi, ataupun dalam arti keseimbangan antara kepentingan individu dan sosial; (3) Kebebasan untuk memilih tindakan atau kebijakan ekonomi, namun hal ini dibatasi oleh perlunya tanggung jawab.

Tanggung jawab manusia minimal ada dua hal, yaitu sebagai pengelola sumber daya yang ada untuk kepentingan masyarakat, dan tanggung jawab dengan mengorbankan kepentingan pribadinya (sukarela) demi mencapai tujuan ekonomi tersebut. Untuk mewujudkan sistem keuangan yang adil dan efisien, maka setiap tipe dan lapisan masyarakat harus terwadahi keinginannya dalam berinvestasi dan berusaha, sesuai dengan kemampuan dan keinginan mereka. Sistem keuangan Islam harus memfasilitasi hal tersebut. Hal ini sesuai dengan ajaran Islam yang diperuntukkan untuk sekalian alam (rahmatan lil 'alamin), dan prinsip bekerja sesuai dengan kemampuan.

Agama Islam memberi perhatian secara seimbang terhadap unsur materi dan unsur ruh. Artinya kedua unsur tersebut dalam daur kehidupan manusia, berhak memperoleh peran yang sama, tanpa ada salah satu unsur yang melebihi atau mengurangi peran unsur lain. Inilah salah satu bagian dari istimewanya ajaran Islam; keselarasannya dengan fitrah manusia. 
Secara fitrah, setiap manusia membutuhkan unsur materi dan ruh, dan keduanya itu diakui oleh Islam. Agama Islam menganjurkan agar keduanya dapat diaplikasikan dalam timbangan yang sama dan sederajat, hingga tak melahirkan kepincangan-kepincangan dalam bersikap. Kita dapat melihat sisi keistimewaan tersebut, misalnya, pada perintah wajib zakat. Perintah zakat, disamping mengandung dimensi materi, juga dimensi ruh. Bila zakat diterapkan secara benar dan menyeluruh, ia memiliki peran sangat esensial dalam pembinaan ruhiyah (tarbiyah ruhiyah), yang selanjutnya akan merealisasikan keadilan sosial dan melahirkan pertumbuhan ekonomi yang sehat dan pesat, disamping semakin memantapkan kekuatan politik untuk umat.

Hal lain yang tak kalah penting, zakat memiliki saham besar dalam dakwah dan jihad yang mutlak menghajatkan harta. Urgensi keterkaitan antara dakwah dan harta, tercermin secara implisit dalam kitabullah. AlQur'an, tatkala menyebutkan batas pengorbanan seorang muslim kepada Islam, umumnya kata "amwal" (harta) selalu diiringi dengan kata "anfus" (jiwa). Dari sini, tampaknya tidak berlebihan bila dikatakan bahwa zakat merupakan sebuah kewajiban yang memiliki efek peran integral, meliputi pembinaan pribadi, keluarga, masyarakat, negara dan terwujudnya khilafah sebagai sasaran akhir dakwah Islam. Oleh karena itu, untuk mewadahi kepentingan masyarakat untuk peran sertanya dalam berzakat, maka telah dibentuk lembaga zakat dimana lembaga ini merupakan lembaga yang hanya ada dalam sistem keuangan Islam, karena Islam mendorong umatnya untuk menjadi sukarelawan dalam beramal (volunteer).

Gerakan kesadaran membayar zakat oleh elemen-elemen masyarakat perlu didukung. Tentunya diiringi tindakan riil dari segenap masyarakat untuk saling mengingatkankan dan menasehati arti penting zakat bagi keselarasan hidup. Atas persetujuan Presiden BJ Habibie dan DPR, Indonesia telah memiliki UU tentang Pengelolaan zakat yaitu UU No 38 tahun 1999. UU ini juga sudah diikuti oleh Peraturan Pemerintah (PP) Nomor 581 tahun 1999 tentang Pelaksanaan UU No 38 tentang Pengelolaan Zakat. Dalam pasal 2 UU No 38 Tahun 1999 tentang Pengelolaan Zakat menyebutkan: "Setiap warga negara Indonesia yang beragama Islam dan 
mampu atau badan yang dimiliki oleh orang muslim berkewajiban menunaikan zakat".

Lembaga zakat sebagaimana tercantum dalam UU zakat adalah lembaga zakat yang dibentuk oleh masyarakat. Lembaga-lembaga ini lingkup operasinya tingkat regional ataupun nasional. Lembaga tersebut bisa dibentuk organisasi politik, takmir masjid, pesantren, media massa, bank, lembaga keuangan dan lembaga kemasyarakatan. Lembaga zakat yang telah berkembang di Indonesia antara lain Badan Amil Zakat Nasional (BAZNAS), Rumah Zakat Indonesia (RZI), Dompet Dhuafa (DD), Dompet Peduli Ummat Daarut Tauhiid (DPUDT), Pos Keadilan Peduli Ummat (PKPU), Baitul Maal Muamalat (BMM), Yayasan Dana Sosial Al-Falah (YDSF) Surabaya dan masih banyak lagi.

Tumbuhnya lembaga-lembaga zakat merupakan cermin timbulnya kesadaran akan perlunya lembaga yang mampu mengelola zakat-zakat masyarakat. Berdasarkan informasi yang dapat dipercaya, potensi zakat seIndonesia Rp. 19,3 triliun, tetapi setiap tahun lembaga zakat se-Indonesia hanya mampu menggali Rp. 625 miliar. Ini pun di dominasi zakat yang berasal dari Luar Negeri. Di sisi lain, banyak hal yang telah dilakukan lembaga zakat dalam membangun kesejahteraan masyarakat. Kepercayaan masyarakat terhadap lembaga zakat dapat diawali dari kondisi lembaga zakat yang baik.

Saat ini yang menjadi trend dari proses Islamisasi (Islamization process) yang dikembangkan oleh para pemikir kontemporer ekonomi Islam adalah mengoptimalkan sistem zakat dalam perekonomian (fungsi redistribusi income). Untuk trend ini sejumlah pemikiran inovatif mengenai intermediary system dikembangkan oleh para ahli ekonomi Islam. Hal ini tentunya diikuti oleh kesadaran bahwa masyarakat muslim sampai saat ini masih dalam sekatan ekonomi terbelakang, artinya permasalahan pengentasan kemiskinan dan kesenjangan sosial (unequality income) dimiliki oleh sejumlah besar negara yang justru berpenduduk mayoritas Islam.

Belakangan ini, intermediary system yang mengelola zakat seperti lembaga pengelola zakat lahir secara menjamur. Untuk fenomena Indonesia sendiri, dunia lembaga pengumpul zakat menunjukkan perkembangan yang 
cukup pesat. Mereka berusaha untuk berkomitmen mempertemukan pihak surplus muslim (muzakki) dan pihak deficit muslim (mustahik), dengan harapan terjadi proyeksi pemerataan pendapatan antara surplus dan deficit muslim atau bahkan menjadikan kelompok yang deficit menjadi surplus.

Adapun penyaluran zakat secara produktif sebagaimana yang pernah terjadi di zaman Rasulullah saw yang dikemukakan dalam sebuah hadits riwayat Imam Muslim dari Salim bin Abdillah bin Umar dari ayahnya, bahwa Rasulullah saw telah memberikan kepadanya zakat lalu menyuruhnya untuk dikembangkan atau disedekahkan lagi. Kaitan dengan pemberian zakat yang bersifat produktif, Yusuf Qardhawi mengemukakan bahwa pemerintah Islam diperbolehkan membangun pabrik-pabrik atau perusahaan-perusahaan dari uang zakat untuk kemudian kepemilikan dan keuntungannya bagi kepentingan fakir miskin, sehingga akan terpenuhi kebutuhan hidup mereka sepanjang masa. Pengganti pemerintah, untuk saat ini dapat diperankan oleh Badan Amil Zakat atau Lembaga Amil Zakat yang kuat, amanah dan profesional. BAZ atau LAZ, jika memberikan zakat yang bersifat produktif harus pula melakukan pembinaan/pendampingan kepada para mustahik agar kegiatan usahanya dapat berjalan dengan baik, dan agar para mustahik semakin meningkat kualitas keimanan dan keislamannya.

Untuk pendayagunaan dana zakat, bentuk inovasi distribusinya dikategorikan dalam empat bentuk berikut: (1) Distribusi bersifat 'konsumtif tradisional', yaitu zakat dibagikan kepada mustahik untuk dimanfaatkan secara langsung, seperti zakat fitrah yang diberikan kepada fakir miskin untuk memenuhi kebutuhan sehari-hari atau yang dibagikan kepada para korban bencana alam; (2) Distribusi bersifat 'konsumtif kreatif', yaitu zakat diwujudkan dalam bentuk lain dari barang semula, seperti diberikan dalam bentuk alat-alat sekolah atau beasiswa; (3) Distribusi bersifat 'produktif tradisional', di mana zakat diberikan dalam bentuk barang-barang yang produktif seperti kambing, sapi, alat cukur, dan lain sebagainya. Pemberian dalam bentuk ini dapat menciptakan suatu usaha yang membuka lapangan kerja bagi fakir miskin; (4) Distribusi dalam bentuk 'produktif kreatif', yaitu zakat diwujudkan dalam bentuk permodalan, baik untuk membangun proyek sosial atau menambah modal pedagang pengusaha kecil. 
Berdasarkan latar belakang masalah di atas maka dapat mengkaji dan menelaah secara ilmiah dan sistematis tentang penyaluran dana zakat produktif melalui pola pembiayaan karena pola distribusi produktif sangat efektif untuk dapat memproyeksikan perubahan seorang mustahik menjadi muzaki. Oleh karena itu dipilihlah badan amil zakat nasional (BAZNAS) Jakarta, karena saat ini BAZNAS telah menjadi Badan Amil Zakat yang bertaraf nasional dan tetap concern dalam memberdayakan zakat, infak, shadaqah bagi kepentingan umat yang masih kekurangan, dan juga melakukan studi kasus di BMT Binaul Ummah Bogor dimana BMT tersebut merupakan salah satu USZ (Unit Salur Zakat) mitra BAZNAS.

Penyaluran dana zakat produktif melalui pola pembiayaan sebagai topik pembahasan karena potensi ZIS di Indonesia sangat besar dan badan amil zakatlah yang mampu menggali zakat, infak, shadaqah umat. Dan ukuran keberhasilan sebuah lembaga pengumpul zakat adalah bagaimana lembaga tersebut dapat menjadi salah satu elemen dari sekuritas sosial yang mencoba mengangkat derajat kesejahteraan seorang mustahik menjadi muzakki. Jika hanya pola konsumtif yang dikedepankan, tampaknya akan sulit tujuan ini berhasil.

\section{METODE}

Data dikumpulkan dari Badan Amil Zakat Nasional (BAZNAS) dan di BMT Binaul Ummah, Bogor sebagai Unit Salur Zakat Mitra BAZNAS. Selama empat bulan yaitu di bulan Februari 2008 sampai dengan bulan Mei 2008. Strategi yang digunakan dalam penelitian ini merupakan strategi yang bersifat deskriptif, yaitu dengan menggambarkan karakteristik atau status secara sistematis, faktual dan akurat, dalam hal ini adalah penerapan penyaluran dana zakat produktif melalui pola pembiayaan pada Badan Amil Zakat Nasional (BAZNAS). Kemudian dianalisis lebih lanjut untuk diambil suatu kesimpulan.

Metode penelitian yang dipilih adalah dengan melakukan survei yaitu teknik pengumpulan data dari subyek yang diteliti (responden) dengan wawancara atau pengamatan. Metode ini digunakan untuk memperoleh fakta-fakta tentang gejala-gejala yang diungkap dalam permasalahan 
penelitian. Selain itu, juga mengadakan studi pustaka dan studi lapangan, yaitu melakukan berbagai pencarian dan pengkajian dengan mengacu pada bahan-bahan yang menunjang tugas akhir di lapangan yaitu Badan Amil Zakat Nasional (BAZNAS) Jakarta. Dalam mengadakan studi pustaka, menggunakan sumber data yang terdiri dari data primer dan data sekunder. Data primer berupa ayat-ayat Al-Qur'an, hadits Rasulullah SAW, dan peraturan perundang-undangan yang berkaitan dengan masalah yang akan diteliti serta data primer lainnya yang menunjang, melalui survei lapangan. Sedangkan data sekunder berupa buku-buku maupun tulisan yang terdapat di media massa dan internet.

Metode ini dilakukan dengan mengumpulkan berbagai data yang berasal dari bahan-bahan pustaka dengan mengadakan studi pustaka dan studi lapangan yaitu melakukan berbagai pencarian dan pengkajian bahanbahan. serta melakukan sortir data. Adapun metode yang digunakan adalah wawancara yaitu: teknik pengumpulan data dengan cara mengadakan wawancara (interview) kepada pihak-pihak yang berhubungan (responden) yaitu sekelompok orang pada badan amil zakat nasional (BAZNAS) dan BMT Binaul Ummah. Dalam hal ini melakukan interview secara lisan maupun tulis. Interview yang di lakukan dapat berupa interview langsung (pertanyaan dijawab langsung oleh responden) maupun secara tidak langsung (daftar pertanyaan yang diajukan dijawab langsung oleh responden).

Metode ini dilakukan dengan menggunakan metode kualitatif. Dengan melakukan inventarisasi terhadap berbagai norma hukum yang terkait dengan distribusi dana zakat secara produktif, dan pola pembiayaan yang dilakukan pada khususnya. Pengumpulan dilakukan terhadap semua azas dan kaidah-kaidah yang terkait dengan permasalahan yang akan diteliti. Adapun teknis analisis yang akan dilakukan selanjutnya adalah analisis kualitatif dengan menggunakan pola pikir induksi dan deduksi. Kedua pola pikir ini dilaksanakan dengan metode interaktif yang terdiri dari tiga jenis kegiatan, yaitu: penyederhanaan data, penyajian data dan penarikan kesimpulan terhadap masalah. 


\section{HASIL DAN PEMBAHASAN}

Mengupayakan timbulnya kesadaran berzakat di masyarakat dan mengusahakan tersedianya kemudahan layanan para pembayar zakat adalah target BAZNAS. Diantaranya dilakukan dengan membentuk Unit Pengumpul Zakat (UPZ) pada banyak Departemen, Badan Usaha Milik Negara (BUMN), dan perusahaan swasta berskala nasional maupun internasional, termasuk diantaranya pembayaran zakat dari luar negeri. Jenis pendayagunaan dana ZIS BAZNAS terbagi ke dalam 6 kategori program yaitu: program kemanusiaan, kesehatan, kualitas SDM, pengembangan ekonomi masyarakat, serta dakwah.

Program pengembangan ekonomi masyarakat merupaan program yang dikembangkan BAZNAS berupa pemberian hak kepemilikan atas aset atau kekayaan dalam bentuk aset usaha kepada mustahik sasaran secara langsung maupun tidak langsung, yang pengelolaannya bisa melibatkan maupun tidak melibatkan mustahik sasaran. Investasi dalam program pengembangan ekonomi masyarakat diarahkan pada aset produktif untuk kepentingan usaha, yang dikelola secara profesional layaknya sebuah usaha yang semestinya. la harus sehat dan berkembang baik. Investasinya bersifat social investment, dan visionary investment.

Investasi, diarahkan untuk memobilisasi potensi usaha mustahik, memberi kesempatan kepada mereka untuk ikut serta memiliki aset potensial dan sumber pendapatan yang lebih berkelanjutan (pendapatan layak sejahtera). Program pengembangan ekonomi masyarakat ini juga harus memiliki daya dorong dan percepatan perkembangan mustahik dalam bentuk: (1) Percepatan pemilikan sarana usaha (alih kepemilikan dan alih kelola), yang konkretnya mengubah posisi ketergantungan mustahik kepada pengusaha/pedagang besar atau pemilik modal pihak lain; (2) Percepatan produktivitas yang melekat didalamnya transformasi daya inovatif, kreativitas, dan penambahan nilai produk; (3) Percepatan penguasaan konsep usaha dan alih teknologi \& manajemen; (4) Percepatan penguasaan pasar dan jaringan. 
Investasi dalam program ini, semua diarahkan pada usaha produktif dan bernilai bisnis, bukan non-produktif dan tak punya daya saing, upaya keras berorientasi bottom up, berpotensi memberdayakan mustahik, sumber daya lokal, halal, thayyib, ramah lingkungan, menguntungkan, dan berkesinambungan, usaha yang mampu menggantikan ketergantungan mustahik sasaran pada pihak atau pemodal lain.

Pola penyaluran BAZNAS menggunakan konsep pemberdayaan berkelanjutan, dengan menggunakan USZ (Unit Salur Zakat) mitra lokal yang tidak hanya menyalurkan namun juga memantau perkembangan kondisi mustahik. Pola ini digunakan oleh BAZNAS karena sangat efektif untuk dapat memproyeksikan perubahan seorang mustahik menjadi muzaki. Selain itu BAZNAS juga melakukan pembinaan/pendampingan kepada para mustahik agar kegiatan usahanya dapat berjalan dengan baik. Dalam penyaluran modal usaha, BAZNAS bekerja sama dengan BMT (dalam penelitian ini, penulis berkunjung ke BMT Binaul Ummah, Bogor) untuk mendistribusikan dana permodalan bagi pedagang dan pengusaha kecil. BAZNAS menentukan mitra BMT Binaul Ummah untuk penyaluran, sedang BMT Binaul Ummah menentukan para pedagang dan pengusaha kecil yang berhak dan mengajukan permohonan pembiayaan dana zakat. Penilaian kelayakan pembiayaan selain didasarkan pada business wise, juga harus mempertimbangkan syariah wise. Artinya, usaha tersebut layak dibiayai dari segi usahanya, dan acceptable dari segi syariahnya. Prinsip penyaluran zakat ditujukan langsung untuk memberdayakan perekonomian umat, dan karenanya diprioritaskan pada kegiatan-kegiatan ekonomi yang produktif. Tidak hanya dalam pendanaannya saja, BMT Binaul Ummah juga berperan sebagai business advisor bagi perkembangan dan kelangsungan usaha mitranya (mustahik produktif).

BMT Binaul Ummah sebagai Unit Salur Zakat mitra BAZNAS telah menyalurkan dana zakat produktif sesuai dengan prinsip aturan syariah. Konsep pembiayaan dana bergulir sebagai modal kerja yang digunakan oleh BAZNAS (dalam hal ini menunjuk BMT Binaul Ummah dalam penyaluran) menjadi konsep yang cukup ampuh dalam mendukung pemberdayaan ekonomi masyarakat kurang mampu tanpa menumbuhkan budaya 
konsumerisme. Sebab salah satu tujuan utama penyaluran zakat adalah untuk membantu kondisi perekonomian mustahik yang sebagian besar merupakan kaum dhuafa. Pembiayaan dana bergulir digunakan oleh BAZNAS untuk menyalurkan bantuan modal kerja bersumber dana ZIS bagi sejumlah pedagang dan pengusaha kecil di Bogor. Hal tersebut karena beberapa alasan. Salah satunya adalah agar dana ZIS yang disalurkan bagi mereka sebagai pembiayaan modal kerja dapat disalurkan kembali kepada pedagang dan pengusaha kecil lain yang membutuhkan. Sehingga dana ZIS dapat membantu semakin banyak pedagang kecil untuk mengembangkan usaha. Terbukti, dana zakat sebesar 40 juta dari BAZNAS yang disalurkan kepada 35 orang pedagang dan pengusaha kecil yang penyalurannya dilakukan melalui BMT Binaul Ummah pada tahun 1995, saat ini mampu menyerap 207 orang pedagang dan pengusaha kecil dengan total pembiayaan Rp. 225.300.000. Adapun sektor usaha yang dibiayai meliputi perdagangan, industri rumah tangga, pertanian, peternakan, jasa, dll. Bagi BAZNAS, program ini merupakan wujud gerakan kepedulian membantu mengangkat martabat ekonomi umat.

Skema apa pun yang dikembangkan oleh BAZNAS, sebenarnya tolak ukur paling utama adalah bagaimana bisa mendekatkan strata kesejahteraan masyarakat deficit kepada strata kesejahteraan masyarakat surplus. Untuk itu BAZNAS tidak perlu takut-takut dalam membuat dan mempolakan sebuah inovasi pendistribusian produktif selama masih dalam frame pemberdayaan dana zakat yang terkumpul. Skema permodalan dan pembiayaan tersebut dapat dikembangkan lebih lanjut sepanjang dipandang baik dan bermanfaat bagi pemenuhan kebutuhan manusia. BAZNAS diharapkan tidak ragu-ragu memberikan pembiayaan kepada usaha kecil, bahkan kepada pengusaha pemula sekalipun. Dalam keputusan menteri agama tentang pelaksanaan UU No. 28 Tahun 1999 tentang Pengelolaan Dana Zakat, Pasal 29 menyebutkan bahwa prosedur pendayagunaan hasil pengumpulan zakat untuk usaha produktif ditetapkan sebagai berikut: (1) Melakukan studi kelayakan; (2) Menetapkan jenis usaha produktif; (3) Melakukan bimbingan dan penyuluhan; (4) Melakukan pemantauan, 
pengendalian, dan pengawasan; (5) Mengadakan evaluasi; (6) Membuat laporan

Berdasarkan hal tersebut di atas BAZNAS telah melakukan pendayagunaan hasil pengumpulan zakat untuk usaha produktif sesuai prosedur yang berlaku. Dengan menyalurkan dana zakat secara produktif melalui pembiayaan yang sesuai dengan syariah, BAZNAS turut mendukung pengembangan usaha kecil yang secara kuantitatif merupakan bagian terbesar dari pelaku ekonomi yang ada di Indonesia. Dan dengan program yang berbasis kemandirian seperti ini, Indonesia diharapkan mampu bangkit dan bersaing dengan bangsa lainnya. Bukan mustahil, bila dua dasawarsa ke depan, Indonesia bisa bangkit dari keterpurukan dengan mengembangkan setiap program yang "memberikan kail" bukan "memberikan ikan" agar masyarakat kita lebih mandiri dan kreatif. Seperti halnya BAZNAS yang optimis mampu mengurangi tingkat kemiskinan di Indonesia dengan program-program yang digulirkannya. Program berbasis kemandirian masyarakat ini mampu menstimulus jiwa masyarakat untuk mandiri, produktif dan meningkatnya kualitas keimanan dan keislaman mereka. Jika zakat bisa dikelola dengan baik seperti zaman Khalifah Umar bin Abdul Aziz, ditambah potensi sedekah dan infak maka Insya Allah masyarakat Islam akan makmur, tidak ada yang kekurangan dan kelaparan.

\section{SIMPULAN}

Setelah menguraikan dan memaparkan tentang "Evaluasi Penyaluran Dana Zakat Produktif melalui Pola Pembiayaan pada BAZNAS" maka ada beberapa hal yang dapat disimpulkan antara lain: Bentuk penyaluran dana zakat produktif yang dilakukan BAZNAS diwujudkan dalam bentuk permodalan. Dalam hal ini BAZNAS berkoordinasi kepada lembaga keuangan (intermediary system) yang berbasis syariah, salah satunya BMT Binaul Ummah Bogor yang kemudian menyalurkan pendanaannya untuk usaha/pedagang kecil. Sehingga BAZNAS dapat benar-benar menjadi partner bagi mustahik untuk pengembangan usahanya sampai terlepas dari batas kemustahikkannya. 
Prosedur penyaluran dana zakat produktif melalui pola pembiayaan pada BAZNAS dilakukan melalui Unit Salur Zakat mitra yang salah satunya adalah BMT Binaul Ummah Bogor yang kemudian menentukan para pedagang yang berhak untuk mengajukan permohonanan pembiayaan dana ZIS. Analisis permohonan pembiayaan dilakukan melalui konsep analisis $5 \mathrm{C}$ (character, capacity, capital, conditions of economic, collateral) yang diterapkan dalam skala yang lebih sederhana.

Pola pembiayaan yang dikembangkan oleh BAZNAS dalam menyalurkan dana zakat pada umumnya mengambil skema murabahah, musyarakah dan mudharabah. Skema apa pun yang dikembangkan oleh BAZNAS, sebenarnya tolak ukur paling utama adalah bagaimana bisa mendekatkan strata kesejahteraan masyarakat defisit kepada strata kesejahteraan masyarakat surplus. Agar tujuan zakat sebagai solusi mengatasi kemiskinan tercapai, kita harus mulai belajar mempercayakan amanah zakat melalui lembaga agar dikelola secara profesional, inovatif, dan tepat sasaran. Sosialisasi dan promosi sadar wajib zakat melalui media baik elektronik atau cetak, bersinergi dengan lembaga non zakat seperti perbankan syariah yang memiliki jaringan yang cukup luas hingga ke daerah. Akuntabilitas, transparansi, dan corporate culture merupakan tiga hal pokok yang menentukan citra lembaga yang amanah dan profesional. Maka BAZNAS harus menerapkan prinsip-prinsip good organization governance yaitu amanah, transparan, profesional.

Pelaksanaan program pemberdayaan masyarakat bukan hal mudah. Untuk membuat program tersebut berjalan sesuai rencana dan tepat sasaran, BAZNAS perlu serius dan memiliki kapabilitas yang cukup. Sehingga penyaluran dana zakat melalui program pemberdayaan masyarakat dapat berjalan dengan baik. Lembaga amil dalam mendayagunakan zakat harus mempunyai program untuk mengubah mustahik beralih menjadi muzaki dengan memberikan bantuan modal usaha dan peralatan kerja. Lembaga amil juga harus memberikan pendampingan, pengawasan, dan pembinaan agar mereka dapat terentaskan dari kemiskinan secepatnya. 
BAZNAS tidak perlu takut-takut dalam membuat dan mempolakan sebuah inovasi pendistribusian produktif selama masih dalam frame pemberdayaan dana zakat yang terkumpul. Agar zakat menjadi institusi strategis bagi penciptaan sistem ekonomi yang adil dan bertanggung jawab, bukan sekedar pemberian untuk menghibur. Tetapi juga mendorong pertumbuhan ekonomi masyarakat berbasis keadilan. Inilah yang menjadi inti ajaran zakat dalam dimensi Islam secara sosial.

Dalam konteks sekarang, penunaian zakat memiliki momentum amat strategis di tengah kondisi masyarakat yang kian menderita. Fenomena makin suburnya pengangguran, kesulitan makan, sulitnya mengakses kesehatan, dan mahalnya biaya pendidikan akibat meningkatnya angka kemiskinan menjadi problem besar bangsa ini. Karena itu, zakat sebenarnya bisa menjadi pelipur lara bagi kaum dhuafa yang amat membutuhkan uluran tangan. Zakat bisa menjadi sahabat dan teman, meski harus kita akui baru sesaat.

\section{PUSTAKA ACUAN}

Antonio, M Syafi'i. 2001. Bank Syariah dari Teori ke Praktik. Gema Insani Press, Jakarta.

Arifin, Zainul. 2000. Memahami Bank Syariah, Lingkup, Peluang, Tantangan dan Prospek. Alvabet, Jakarta.

Badan Amil Zakat Nasional (BAZNAS). 2006. Annual Report. Jakarta.

Harahap, S Syafri. 2001. Menuju Perumusan Teori Akuntansi Islam. Pustaka Quantum, Jakarta.

Hafidhuddin, Didin. 2002. Zakat dalam Perekonomian Modern. Gema Insani Press, Jakarta.

Hafidhuddin, Didin. 2007. Agar Harta Berkah dan Bertambah. Gerakan Membudayakan ZIS dan Wakaf, Gema Insani Press, Jakarta.

Hafidhuddin, Didin. 2008. Panduan Praktis tentang Zakat Infak Sedekah. Gema Insani Press, Jakarta.

Mursyidi. 2003. Akuntansi Zakat Kontemporer. PT. Remaja Rosdakarya, Bandung. 
Mufraini, M Arif. 2006. Akuntansi dan Manajemen Zakat. Prenada Media Group, Jakarta.

Qardhawi, Yusuf. 2007. Hukum Zakat. Litera Antar Nusa, Jakarta.

Rifa'i, M. 1978. IImu Fiqh Islam Lengkap. CV. Toha Putra, Semarang.

Ritonga, A Rahman dan Zainuddin. 1997. Fiqh Ibadah. Gaya Media Pratama, Jakarta.

Shiddieqy, H. 1984. Pedoman Zakat. PT. Bulan Bintang, Jakarta.

Sudarsono, Heri. 2004. Bank dan Lembaga Keuangan Syariah. Ekonisia, Yogyakarta.

Sula, M Syakir. 2004. Asuransi Syariah, Konsep dan Sistem Operasional. Gema Insani Press, Jakarta.

Wijaya, Taufik. 2006. Metode Penelitian. STAI Tiara, Jakarta.

Yahya, M Ridwan. 2006. Fiqh dan Amaliyah Zakat. Pustaka Nawaitu, Jakarta. 